\title{
The Personality of $M \dot{\eta} \delta \varepsilon \imath \alpha($ Medea): An Ethical Approach
}

\author{
Evaggelia Kiosi \\ National and Kapodestrian University of Athens, Zografou, Greece \\ University of the Peloponnese, Kalamata, Greece
}

\begin{abstract}
$M \eta \dot{\delta} \varepsilon l \alpha($ Medea), the tragedy written by Euripides (431 BC), refers to the story of a woman who seduced by her love for Jason, left her hometown of Colchis, and flew with him to Greece. Jason then betrayed Medea and got married with the daughter of Creon, King of Corinth. Medea, in order to get revenge, killed both Jason's bride and his father-in-law, and then, after slaughtering her own children, she left to Athens. The approach of Medea's personality, as a subject of this paper, takes place in the light of the ethical philosophy through comparative quote mainly of the representatives of the spirit of that period, sophists and Socrates, but also of later philosophers, such as Immanuel Kant. This contribution aims to demonstrate the timelessness of human experience through the centuries and explain why the literature of other cultures and eras continues to be of interest.
\end{abstract}

Keywords: ethical philosophy, Kant, Medea, Socrates, sophists

\section{Introduction}

The study of $M \dot{\eta} \delta \varepsilon l \alpha$ (Medea), the tragedy written by Euripides and played in Athens in $431 \mathrm{BC}$, reveals that it is a work that highlights elements of social concern, at a time when the classical Greek world was ready to pass through the internal conflict and the phase of its decline. The philosophy of the time, under the influence of the sophists' movement, had already taken a new path with the interest of finding out about human and his/her position in society.

Euripides was following the sophists, but also Socrates, with whom he maintained a long friendship.

Characteristics of the sophists' philosophy were (Guthrie, 2003):

a. Empiricism regarding the general philosophical view of things.

b. Skepticism about the possibility of acquiring certain knowledge. The sophist Protagoras used to say "What seems true to me is true to me and what looks true to you is true to you" and therefore no one is able to refute the opinion of the other.

c. Relativism of values: Value exists only in law, not in nature. According to Euripides, a person asks "What act is shameful if it does not seem so to the one who does it?"

At a time when criticism of traditional values was present in every political and social institution, Euripides, concealing in his work his active interest in society, doubted about everything, sought both divine and human, and analyzed human nature, instincts, passions, and motives with realism (Giatromanolakis, 1990). The difference from the other great tragic poets, Aeschylus and Sophocles, is that Euripides turned the lights to

Evaggelia Kiosi, MPhil., "Ethical Philosophy", Department of Philosophy, Faculty of Philosophy, Pedagogy, Psychology, School of Philosophy, National and Kapodestrian University of Athens, Zografou, Greece; Department of Philology, School of Humanities and Cultural Studies, University of the Peloponnese, Kalamata, Greece. 
the faces of the myth and not to the myth itself. In this way, the tragedy acquired more inner content, as conflict was being experienced within the tragic hero, where the contradictions, as a characteristic of the human soul, were neither concealed nor adorned (Euripides, 1994).

Medea was the woman who seduced by her love for Jason, left her hometown of Colchis, and her family and flew with him to Greece. Jason then betrayed Medea and his children and got married with the daughter of Creon, King of Corinth. Medea, in order to get revenge, killed both Jason's bride and his father-in-law, and then, after slaughtering her own children, she left to Athens, to the deep regret of her betrayed husband.

The ethical approach of Medea's personality, as a subject of this paper, takes place at the following directions:

a. Description of Medea's innate qualities and behavior, as an expression of her way of existing and a reaction to the stimuli of the outside world-always in line with her position in a particular place and time;

b. Promotion of her moral character, referring to her capacity as a person who acted or evaluated her actions in accordance with certain and fixed ethical rules;

c. Comparative quote of philosophy on knowledge and virtue, mainly of the representatives of the spirit of that period, sophists and Socrates, but also of later philosophers, such as Immanuel Kant;

d. Demonstration of the position and value of Medea's personality today.

\section{Nature and Position of Medea}

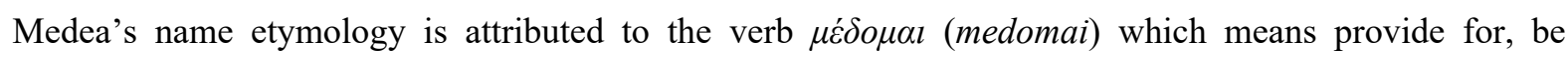
mindful of, but also plan, contrive, and devise (always in bad sense) (Dimitrakos, 1956). ${ }^{1}$

Medea, according to mythology, claimed a royal and divine descent, as she was considered to be the daughter of the King of Colchis Aeite and of the Goddess-witch Hecate. Pindar describes her as a "venomous

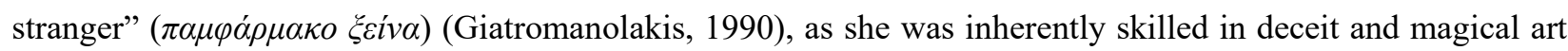
[verses (v.) 384-385]. She was "barbarian" ( $\beta \dot{\alpha} \rho \beta \alpha \rho \eta$, varvari) in a society that treated foreign women as peculiar, as individuals that acted inappropriately to their gender and capable of even committing homicide with inhuman cruelty (Giatromanolakis, 1990).

Medea's vengeful nature, which led her to murder by fraudulent means, is revealed in the first verses of the tragedy, when she mentioned Pelia's murder (v. 10) and the extermination of her brother (v. 166). On the part of Medea, those actions took place as punishment and retribution for the "evil" she had suffered in a cruel way, revealing a lack of human feelings and compassion. The story of her innate vindictive nature, according to the legend, ends with the murder of Creon and his daughter, as well as the extermination of Medea's own children, for punishment to her husband, Jason, because of the wedding betrayal.

Medea was a married woman and a mother at a time when, in classical Greece, the female duty was limited to the home, without political rights and without a particular social presence. Medea underlined women's stressful position at that time ${ }^{2}$ describing marriage as a form of slavery (v. 230-250), but also, on the other hand, speaking of marriage in an idealistic way, referring to wedding vows and reciprocity (v. 20-23, 160-165). The wedding vow meant for Medea a promise of everlasting faith, representing absolute trust and

\footnotetext{
${ }^{1}$ In its active form, the verb ( $\mu \varepsilon \dot{\delta} \delta \omega$, medo) acquires a completely different meaning: protect, rule over.

${ }^{2}$ In ancient Greece, women had no right to seek a divorce. In Athens, however, they could have asked the Lord to abandon the marriage, but that was objectionable, too. Here Euripides examines the fundamental values of ancient Greek culture, demonstrating a society that had systematically underestimated women's presence in the process of social evolution
} 
self-sacrifice. What infuriated her most were humiliation and the break of the wedding vow, an important bond between humans. Medea would not allow anyone to "pain her heart" (v. 398) nor she would "suffer mockery" (v. 404).

The human promise became inviolable when humans swore to the Gods. Medea invoked Themis, the Goddess-protector of justice and oaths (v. 160). She also obliged Aegeus, King of Athens to swear to the Gods that he would protect her as long as he lived (v. 749-750). After securing her salvation (v. 744-755), Medea developed her murderous plan, considering the Gods to be her supporters. "By oath you become a friend of the Gods", acquiring a pretext against your enemies, which was an unwritten law for Medea.

According to the tragic poets, the unwritten laws were of divine origin, as they were the "unwritten commandments of the Gods". The religious background of this idea meant that prosperity based on bad human

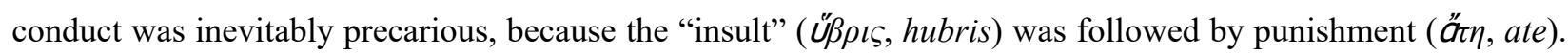
The doctrine of the unwritten laws applied to all ages and to all people. These laws were rooted in nature and were, at the same time, set by the Gods, having a high moral tone. The unwritten laws presented the ancient philosophical tradition, which the new ethics of the sophists' movement called into question (Guthrie, 2001).

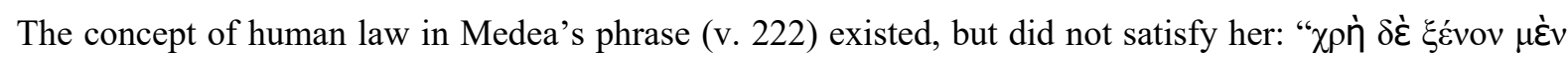

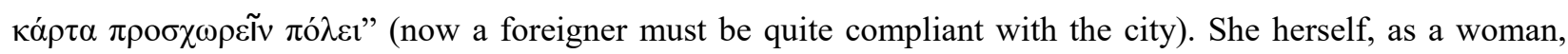
took justice into her own hands, "defying the Gods", said the chorus (v. 414-420), "fulfilling the law", Medea said below.

The dipole "Law-Nature" (Nó $\left.\varsigma_{-\varsigma}-\Phi v ́ \sigma \iota \varsigma\right)$ in the fields of ethics and politics has been at the core of Greek thinking, especially in 500 and $400 \mathrm{BC}$. "Nature" ( $\Phi \dot{\sigma} \sigma l \varsigma$ ) meant something natural and true. Law (Nó $\mu \circ \varsigma$ ) was something that was considered right in practice, initially something that was granted and applied as something artificial and sometimes wrong, though generally was believed as right. The exclusion of the divine element from luck and physical necessity as causes was used by the sophists, proponents of the relativism of moral concepts who denied that there were absolute criteria for law and justice. The law was imposed not by the Gods, but by humans as an agreed restriction of liberty. (Guthrie, 2001, pp. 80-86)

For Medea, Jason was brutal and hypocritical (v. 465, 470-472), disrespectful towards the Gods: "ő $\rho \kappa \omega v$

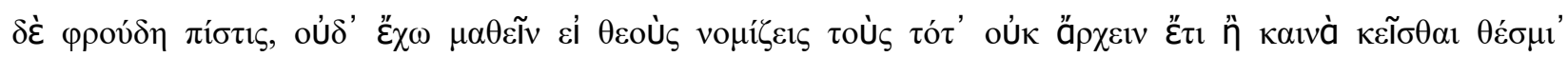

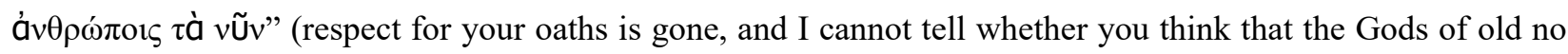
longer rule or that new ordinances have now been set up for mortals) (v. 492-494). Jason was selfish, insincere, because he was acting for its sole self-interest, in a way that went beyond what was permissible, summarized

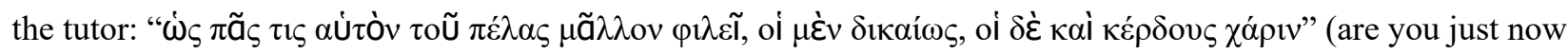
learning this, that each man loves himself more than his neighbor, [some justly, others for the sake of gain]) (v. 86-87).

The sophist Protagoras argued that every human being is right, because he/she sees one side of the truth, the one that allows him/her his/her own disposition to see. But there are normal and abnormal dispositions, that is, stronger or weaker (not right or wrong). All judgments are equally valid, but not of the same value. An orator has the most normal, strongest, and best doctrine identified with wisdom, as he/she is trained to see both sides of the truth (Guthrie, 2001).

Jason was dishonest (v. 498), as he showed a lack of sincerity, and attempted to rhetorically pretend the benefactor (v. 580-587). Because of his dishonest, deceitful, and disrespectful behavior, Medea detested him.

Medea attributed a remarkable wisdom to her feminine nature, when Creon (v. 285) called her "a clever 


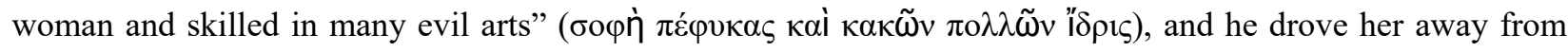
Corinth.

The Greek words $\sigma o \varphi o ́ \varsigma-\sigma o \varphi i \alpha$ (wise-wisdom) have been in common use since ancient times. At the beginning, "wise" meant mainly the skilled person in a particular art (specialist). Later, "wise" became the one who knew something (well-informed) or the prudent. A term such as this one with an evaluative content inevitably runs the risk of dividing its meaning into true and false, depending on the perspective of the person using it. At the same time, there is a hint that the "wise" man remains intelligent and is likely to fall victim to his own intelligence. For Euripides, when people try to overcome Gods they are smart, but not prudent (Guthrie, 2001). ${ }^{3}$

In Corinth, Medea was secretive and did not disclose her true thoughts and intentions. She lied to Creon in order to achieve her purpose (v. 310), begged for mercy for her children by pretending (v. 345), and did good deeds for profit and fraud (v. 370). She planned her escape (v. 390) and, after securing it, she pretended the repentant, who "reasonably" seek reconciliation with Jason (v. 870-950).

In addition, Jason attributed to Medea "a clever mind" (v. 529) and Aegeus "a wise mind" (v. 677). Medea, by her side, claimed a role of a rogue orator, according to the male standards of the sophists' era, in order to manipulate Creon and win the time needed to fulfill her plans. Later, Medea promised to Aegeas the possibility of childbirth (v. 717-718) in order to ensure her escape and preserve her life, proving that persuasion, when added to words, can shape the human mind as it wishes (Guthrie, 2001). ${ }^{4}$ Even in the rhetorical struggle with Jason in many ways, justice was in favor of Medea.

Jason rejected Medea's arguments as products of female irrationality (v. 570) and stubbornness (v. 621) and cursed her female nature (v. 574). He considered marriage a social and economic contract, as he spoke in terms of material prosperity and security, neglecting vows and faith. So as presented in the tragedy, Jason was self-righteous and utilitarian. The arguments he used to defend his actions showed that he had studied rhetorical art, but it was precisely the professionalism of his arguments that made no sense. His arguments were spelled out precisely and his excuses, although well-organized, appeared to avoid important issues. He presented himself as a benefactor of Medea and his children, saying that he had brought them to Greece, a favored land (v. 536, 549, 560). According to Jason, his new marriage did not happen because of love, but for everybody's favor in order they to live with every kind of comfort (v. 596, 610). He used rhetoric art to recreate the truth as he wished it to be.

Medea herself, in her view, was a practical example of her principles when she followed Jason leaving her homeland, thus showing complete trust in her husband and the wedding vows. She repeatedly saved his life and completed for his sake the deeds he could not accomplish (v. 476), she was hurt for his own good, and finally she became hated (v. 506-508).

\section{The Character of Medea}

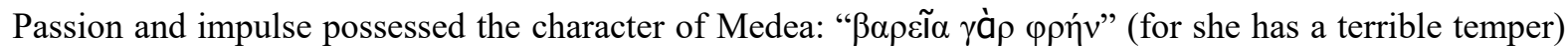

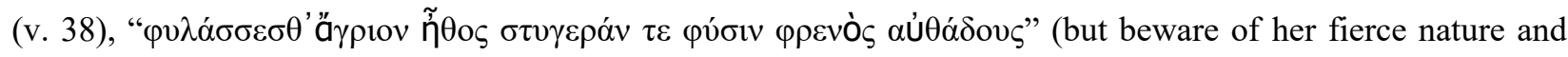
the hatefulness of her wilful temper) (v. 102-104). Driven by her love, rather than by her prudence, as she said

\footnotetext{
${ }^{3}$ Socrates, instead, claimed that "one (thing) I know, I know nothing" (

${ }^{4}$ In Euripides' dialogues we observe the rhetorical style, dominant in classical Athens. Probably this reveals the effects of the sophists' movement.
} 
(v. 485), she caused many deaths.

Her passion had no moderation ( $\mu \varepsilon^{\prime} \tau \rho o$, metro), and for this reason the nurse said (v. 125-130):

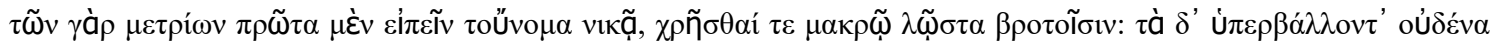

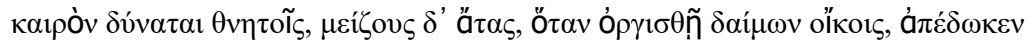

for moderate fortune has a name that is fairest on the tongue, and in practice it is by far the most beneficial thing for mortals. But excessive riches mean no advantage for mortals, and when a God is angry at a house, they make the ruin greater.

Socrates argued that, if we could understand our own nature, we would know what is the right and natural purpose of our lives and this knowledge would give us the virtue we seek. It does not depend on our will to be good or bad, because no one prefers injustice but only justice. Moderation or restraint (prudence), according to Socrates, consists of the knowledge of good and bad and the use of the so-called "goods of life" with prudence and wisdom. Socrates refers, as an example, to the virtue of courage ( $a j \delta \rho \varepsilon i \alpha$, andreia) which, without knowledge, is a reckless boldness. It all depends on making the right decision and what is required for the right choice of pleasures is the art of moderation (Guthrie, 2001).

The chorus invoked prudence (v. 638), the first gift from the Gods, and below recommended Medea to

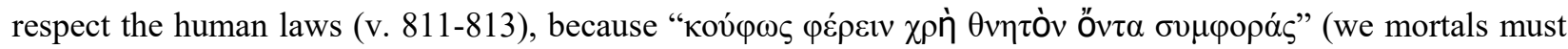
bear misfortune with resignation) (v. 1018). After the massacre of the children, the chorus stressed dislike for the atrocious crime (v. 1260) citing divine judgment (v. 1270).

The sophist Protagoras claimed that virtue was not a natural human asset, as Socrates argued, but man using his/her innate intelligence and innate potential for moral progress could acquire virtue through teaching and effort. According to the ancient Greek legend, Prometheus offered to people logic and wisdom in the arts.

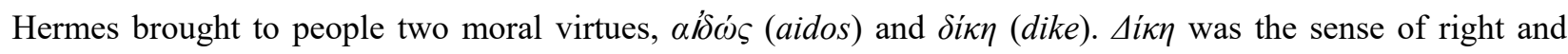
justice, while $\alpha \delta \dot{\delta} \omega \varsigma$ was the sense of shame, modesty, and respect for others (consciousness). Self-restraint and a sense of justice were essential to the existence of a society, which in turn was a prerequisite for human survival. Laws were guidelines set by the state to teach its citizens the limits within which they could act without violating them (Guthrie, 2001).

Euripides' ethics of avoiding "pride" ( $\gamma \alpha$ ópov) meant that the ideal was a man of average status who observed the rules defined by the state (Guthrie, 2001).

Jason who was for Medea the whole world proved to be evil and cruel (has proved the basest of men, v. 228-229). His obscene betrayal of love left Medea socially and emotionally exposed that was alone in a foreign land, without the support of her own people (v. 256-259). She felt ashamed (v. 24-26), suffering, and mourning and she was wishing to die (v. 96-98, 145-148, 226-227). Medea's miserable psychological mood was revealed

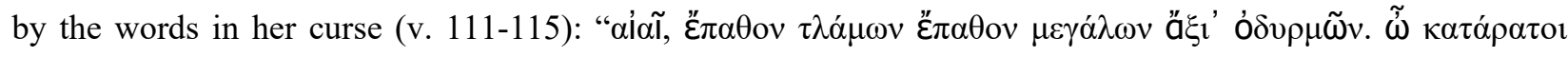

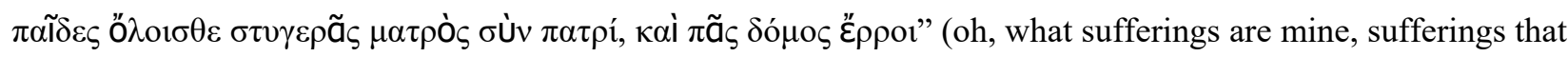
call for loud lamentation! O accursed children of a hateful mother, may you perish with your father and the whole house collapse in ruin!).

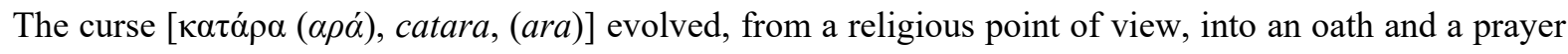
[( $\pi \rho \circ \sigma \varepsilon v \chi \dot{\eta}\left(\varepsilon \dot{U}_{x} \eta^{\prime}\right)$, prosefhi, prayer (efhi, wish)] (Liddell \& Scott, 1940). From a sociological point of view, it had become an institution and, finally, a law. That is why the early legal rules required the curse to be approved. The law did not specify what the citizen should and should not do. However, it was considered, "cursed" the 
one who acted in a way contrary to what he/she was pledged to do. That is what Medea argued: Jason simply did not do what he was pledged to do, and thus he was punished in the form of divine judgment.

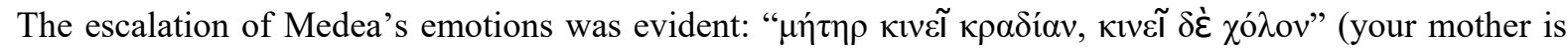

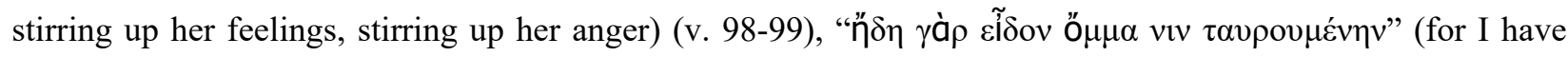

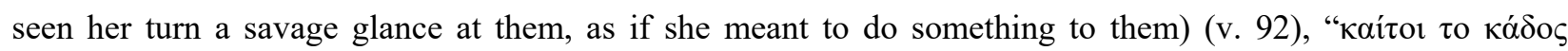

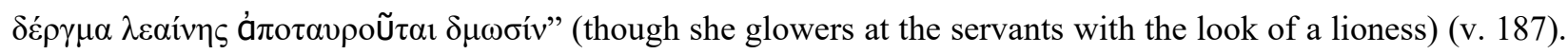

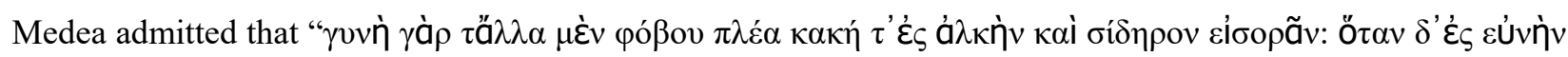

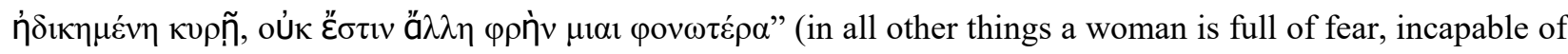
looking on battle or cold steel; but when she is injured in love, no mind is more murderous than hers) (v. 264-266). In front of the betrayal of love, the woman becomes the toughest killer and the chorus recognized it. Following Creon's exile command, Medea then felt the overt hostility to her face (v. 277-278, 439-445).

The depth of Medea's passion became anger, overt rage, hatred, and thirst for revenge. The poet perfectly illustrated the degree of mania and savagery a deceived spouse could achieve and how much insanity could result from marital fraud (Guthrie, 2001). ${ }^{5}$ Hate, as the overwhelming feeling of intense hostility that causes man to desire evil for the one against whom he turns, was deeply rooted within Medea. In v. 15-16, the nurse

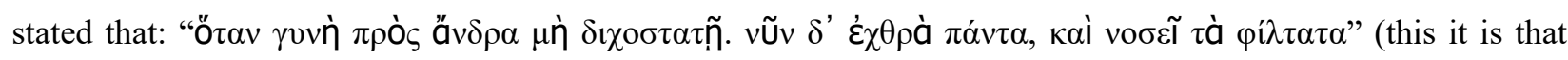
most rescues life from trouble, when a woman is not at variance with her husband, but now all is enmity, and love's bonds are diseased). In a soul that such hatred was born, the strongest love could also blossom (v. 431-433). So, it was Medea, a powerful personality, but she used the power of her soul in a special way, which

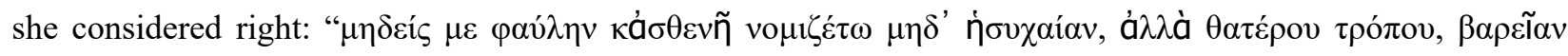

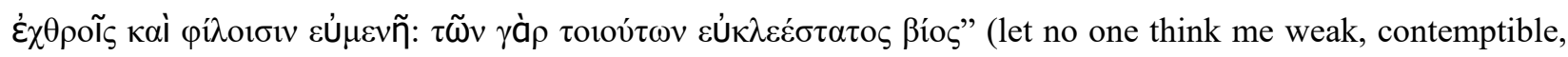
untroublesome. No, quite the opposite, hurtful to foes, to friends kindly. Such persons live a life of greatest glory) (v. 808-811), because Jason "had been unfaithful to his family" (v. 698).

In Plato's Republic (353b), Socrates claims that there is a particular virtue that belongs to anyone who must perform a particular function or task. He proceeds with the view that the human soul also has its function, that is, to govern the lower parts of the soul, to make decisions and generally to secure a life that is the best that man can live. This virtue must be identified with justice. Nothing is worth compared to mental health, which is highly dependent on self-knowledge (Guthrie, 2001; 2003).

For humans, the highest pursuit of their spirit is a concept of justice, according to Socrates, who states in

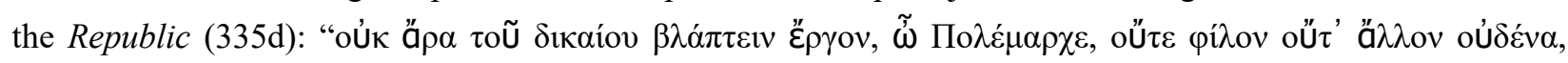

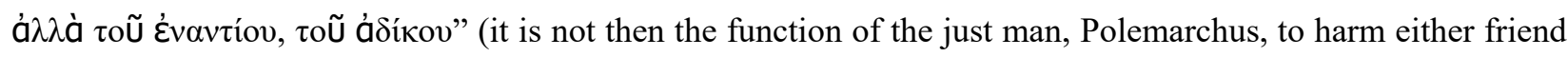
or anyone else, but of his opposite).

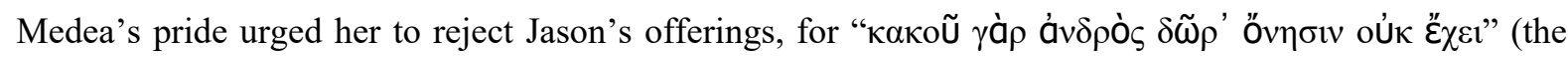
gifts of a base man bring no benefit) (v. 618), and she preferred death (v. 392-394) to a second exile. A special and justified pride-"boldness", as Medea called it (v. 394, 403), which, however, would lead her to untold acts.

In summary, it could be said that Medea considered her judgment to be just because she did not harm Jason (v. 692). Instead, Jason had harmed her (v. 220-230) and she would reattribute with the help of the Gods (v. 802).

\footnotetext{
${ }^{5}$ According to Euripides, "nature wanted it, that doesn't care about the law" and that is the excuse of a woman who sinned, because so are the women.
} 
Socrates believed that one should obey the laws in every case, even though they do not exist by nature, as a key element of justice, and that the state whose citizens obey the laws is strong and prosperous. In Crito, if every individual, depending on his/her whim, could ignore the law's mandates, the foundations of state life would collapse. According to Socrates, the life of every citizen was the implementation of a contract or a treaty. In return for the benefits provided by the laws, every citizen was obliged to regard the laws as masters to whom he/she owed obedience. Violation of this principle would destroy the whole society. Socrates also mentioned the unwritten laws that are universally enforced and enforced by the Gods (they are not rules of nature). Obeying these laws is beneficial to the individual, because unlike human laws, it is not possible to neglect them with impunity. The sporadic infringement of a law does not invalidate its validity, and people can escape punishment, but this never happens in case of infringement of the divine laws (Guthrie, 2001; 2003). ${ }^{6}$

Even after the murder of her children, Medea said that the Gods knew the good that she had done to Jason (v. 1351) and the evil that he had done to her (v. 1372). The Gods knew who had begun the evil.

The concept of God existed and played a role in Medea's morality only with regard to the oath. But Medea herself was the punisher and her revenge (or divine judgment) was an important issue. It is surprising the fact that, despite the cruel nature of her crime, audience's potential attraction to Medea is as strong as her charm to the chorus.

\section{The Moral Personality of Medea}

Medea's decision to seek revenge was stated from the beginning with characteristic logical precision (v. 260, 375-376). She firstly discussed the possible ways to murder Creon and his daughter (v. 378-380) and, from v. 770 , she began making a plan of execution that, perhaps, causes detest. She used her own children to carry the murderous gifts to Creon's daughter (v. 950) and, when father and daughter found a tragic end, rejoiced at their loss (v. 1135). Jason deserved the worst punishment, which was not death: She had to slaughter her children (v. 792), because her husband would thus be harmed (v. 817).

According to Kant, what found our moral obligations should not be sought within human nature or external circumstances, because they are controversial and none of us knows exactly what he/she wants. Human moral obligations should be sought only "a priori", that is, in the notions of logic that are common to all human beings. Indeed, the philosopher argues that any rule based on empirical principles and that has at least empirical foundations can certainly be called as "practical rule" but never as "moral law". Our ethical obligations are related to our duties stricto sensu, so they cannot be exempted to the benefit of the tendency (Pantazakos, 2007).

Medea was struggling with herself because her insane decision conflicted with her instincts (maternal instinct), she was constantly revising (v. 1015), admit her "helpless" mind and her futile stubbornness (v. 1029).

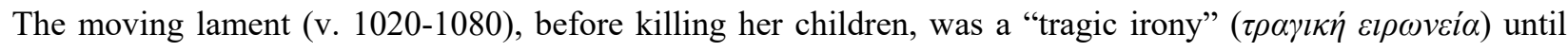
she finally decided to carry out her devious plan:

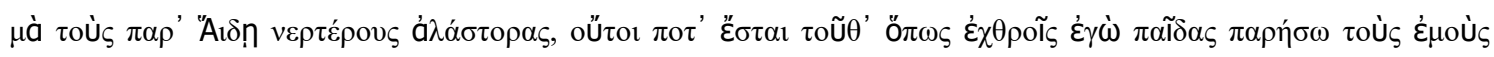

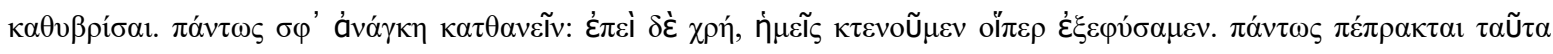

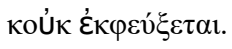

by Hell's avenging furies, I shall never leave my children for my enemies to outrage. They must die in any case. And

\footnotetext{
${ }^{6}$ When Socrates identifies justice with law, he includes both universal divine and unwritten laws and has in mind the judgment, not only in the present life but also in the future.
} 
since they must, the one who gave them birth shall kill them. These things are settled in any case and cannot be undone (v. 1059-1065).

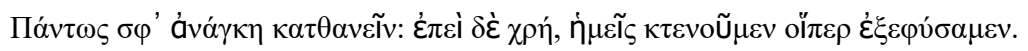

they must die at all events, and since they must, I who gave them birth shall kill them. (v. 1240)

This is where the struggle between consciousness and desire or the weakness of will arises.

Socrates claimed that no pleasure could surpass the pleasure of quiet conscience, and no pain, even if it included poverty, humiliation, wounds, and death, could overcome it. It is preferable, even less painful for the person who knows, to be disadvantaged rather than to disadvantage, because what is important is the soul, not the body or the phenomena. Prospering and enjoying the so-called "pleasures" by selfish and unjust means is an injury to one's own soul (Guthrie, 2001).

Ancient Greek philosophers attempted to address various issues through logic. According to the philosopher De Carte, the soul, besides the intellect, also includes the will. The mission of the intellect is to obtain the truth through the clarity of the meanings, while the work of the will is to affirm or deny the findings of the intellect. Contrary to logic that it is bound by the strict principles of the intellect, the will is unlimited. According to Kant, knowledge is the product of the "theoretical reason", while the "practical reason" is identified with the will, in particular the "pure will". "Pure will" is based only on itself and this is where the human moral behavior derives from. "Empirical will" is dictated by factors beyond itself and it is identified with desire, pursuit or even purpose (Pelegrinis, 2005).

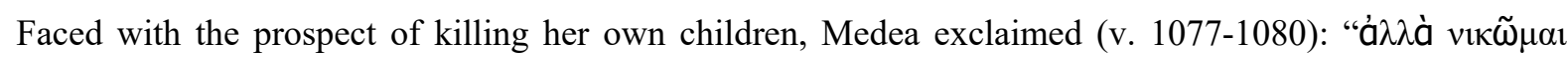

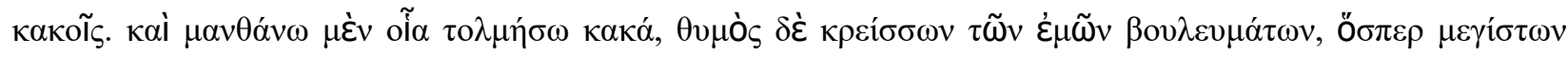

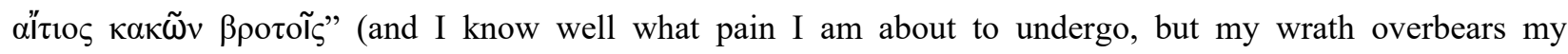
calculation, wrath that brings mortal men their gravest hurt).

According to Socrates, all that one man could give to another by teaching was knowledge. So if virtue, which clearly included moral virtues, can be taught, then it is a form of knowledge. But if virtue is knowledge,

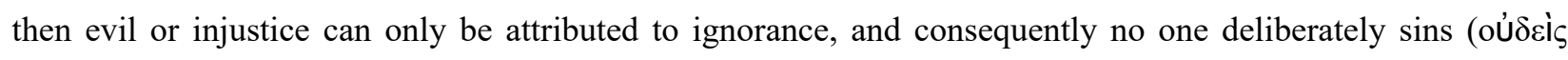
$\dot{\varepsilon} \kappa \dot{\omega} v \kappa \alpha \kappa o ́ s$, oudeis econ cacos [no one is bad at will]). Right practice will automatically follow the knowledge of what is right. Socrates held the heroic doctrine that "no evil can happen to a good man". He admits to

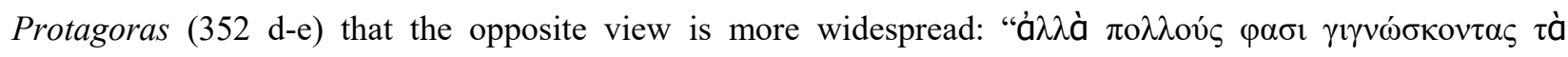

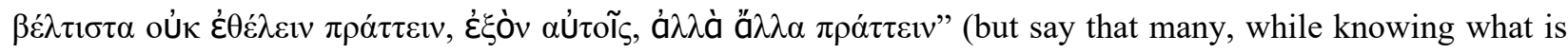
best, refuse to perform it, though they have the power, and do other things instead) (Guthrie, 2001).

In this position that appears once again the "nature" with its "necessity", this refuge found by people with a weak will in their despair. It is about a competition of the tendency towards the moral rule, which alters the universality of a principle (universalitas) in simple generality (generalitas), so that the principle of "practical logic" is "falsely compatible" with the ethical rule (Pantazakos, 2007). Making an exception to her moral

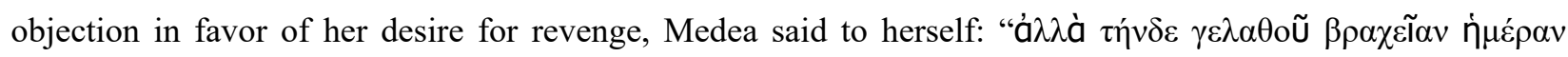

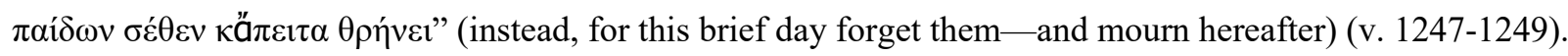

"In ethics", Kant said,

the imperative cannot be hypothetical, that is it cannot express the practical necessity of a potential act as a means of something else that we want. The imperative can only be categorical, that is it must express the objective necessity of an action, irrespective of any other purpose. It is a mistake to regard moral wills acts such as instincts, natural inclinations, appetites, passions or emotions, because they are not dictated by our "pure will", but always by something outside it. 
(Pantazakos, 2007)

After the murder of her children, Medea told Jason that he had been irreparably hurt in the way she wished (v. 1360) and, therefore, the responsibility was his own (v. 1364). To the end, she punished him by not letting him mourn and bury his own children (v. 1375). She reminded him that she let him live to suffer (v. 1395). Her

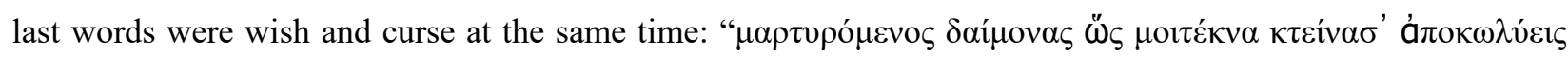

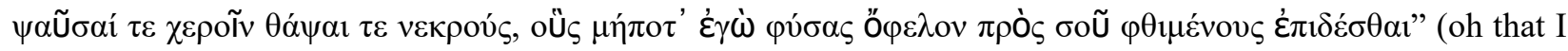
had never begotten them, never seen them dead at your hands!) (v. 1410-1414). And she left on the chariot of the Sun.

The drama of Medea was that she knew, but she still acted, and she did not act because of necessity or instinct, but through choice that was based primarily on emotions (passion) rather than pure logic. When she made the decision to execute her children she knew what was right to do, yet she decided to do the opposite. The reason why she could not do what her moral rule defined was not outside of her, but it came from herself and it was her passion (Pelegrinis, 2009; Guthrie, 2001). Medea did not act freely, but out of her pure will, because she was defeated by her own "nature" that was contrary to the law.

According to modern criminal law, an offender's guilt is analogous to his/her attitude towards the subject of the crime, in other words his/her intention. This subjective element of guilt is divided into cognitive and by volition. These two measures determine the degree of responsibility. As a result, we are talking about crimes committed deliberately or negligently. The imputation is not the same as deceit or negligence, but it is the accusation we personally ascribe to the perpetrator; it is a judgment of worthlessness; it is a disapproval of the behavior of one who was able to decide freely between justice and injustice. The criminal is the one who, while he/she was able to control his/her conduct in accordance with the values of general social acceptance and the rules of law, and therefore able to suppress his criminal impulses, nevertheless decided and committed the crime (Filippidis, 1993). ${ }^{7}$

Medea, from the ethical philosophy's perspective, did not constitute a moral personality, although it was a person who was the source and cause of her actions and she was the actor who gave sense to her actions. Although the concept of will may, possibly, be the base concept of criminal responsibility, Medea's subjective rule had no moral content because, despite her strong and rigid character, she acted because of indignation and hatred. In accordance with the "duty" considered by her point of view (revenge), Medea decided and acted selectively, for that particular case.

\section{Conclusions}

What characterizes a moral person is the responsibility he/she takes on his/her actions, which cannot be understood without the freedom to choose the principles from which it derives, in other words his/her debt. Everyone, as a moral person, is free and has the right to choose his/her principles (Pelegrinis, 2005). Really free is only the person who is not under the influence of any psychological cause, passion, addiction, or tendency either internal or external.

The man of modern times makes decisions through will and then acts, thereby rendering himself/herself, not only to the cause of his/her actions, but also to an existence that shapes the future itself. In practice, of course, it is not always easy to detect when an emotion should be considered so powerful that it makes us

7 This is a necessary condition for the imposition of a penalty (nullum crimen, nulla poena sine culpa). 
irresponsible and when not, as well as when an action is forced upon us and when it comes from pure logic. The main difference between humans and animals is that humans have abundant lifestyle choices, they can be ethical persons, and their behavior is perfectly intertwined with the worth and value they recognize in themselves and in other human beings. The evaluation of things is a determining factor of our behavior and attitude towards them.

It is not, therefore, the freedom of the will as the mere choice of many solutions, but the capacity we have as humans for unlimited perfection. This ability should, according to Socrates, urge us to achieve self-knowledge ( $\left.\gamma v \tilde{\omega} \theta l \sigma \alpha U^{\prime} \hat{t}^{\prime} v\right)$. This does not refer to the ability of human egoism to reach its extreme limits, but to its pettiness in front of the mysteries of the universe.

The timelessness of Medea's tragic persona is verified by daily reports in similar cases, where the characterization of Medea is symbolized and tragically describes the person to whom it refers, but at the same time, verifies the timelessness of the ancient Greek tragedy. The feelings of a woman whose love has turned into hatred, as well as the feelings of a man who no longer loves, represent something eternal and unchanging within human nature.

Here is what we should always look for in the great drama: universal within special. Literature can fully understand the human experience and explore real feelings. The common existential problems that all cultures face explain why the literature of other cultures and eras continues to be of interest.

\section{References}

Dimitrakos, D. (1956). The great dictionary of Greek language. Athens, Greece: Dimitrios Dimitrakos Publications.

Euripides. (1994). Medea. Athens, Greece: Cactus Publications.

Filippidis, T. (1993). Forensic psychology. Thessaloniki, Greece: Kyriakides Bros Publications.

Giatromanolakis, G. (1990). Euripides's Medea. Athens, Greece: Kardamitsa Publications.

Guthrie, W. K. C. (2001). Socrates. Athens, Greece: National Bank of Greece Cultural Foundation (MIET) Publications.

Guthrie, W. K. C. (2003). The sophists. Athens, Greece: National Bank of Greece Cultural Foundation (MIET) Publications.

Liddell, H. G., \& Scott, R. (1940). A Greek-English lexicon. Oxford: Clarendon Press.

Pantazakos, P. (2007). Duty and obligation in Immanuel Kant. Scientific Yearbook of the University of Athens School of Philosophy, 38(16), 229-246.

Pelegrinis, T. (2005). Lexicon of philosophy. Athens, Greece: Hellenica Grammata Publications.

Pelegrinis, T. (2009). Ethical philosophy. Athens, Greece: Hellenica Grammata Publications. 